\title{
PENGEMBANGAN PERANGKAT PEMBELAJARAN MATEMATIKA BERBASIS PEMECAHAN MASALAH PADA MATERI PYTHAGORAS KELAS VIII SMP
}

\author{
Novika Safitri Istiqomah \\ Pendidikan Matematika, Fakultas Matematika dan Ilmu Pengetahuan Alam, Universitas Negeri Surabaya \\ novikaistiqomah16030174099@mhs.unesa.ac.id

\section{Ika Kurniasari} \\ Jurusan Matematika, Fakultas Matematika dan Ilmu Pengetahuan Alam, Universitas Negeri Surabaya \\ ikakurniasari@unesa.ac.id
}

\begin{abstract}
Abstrak
Perangkat pembelajaran ialah kumpulan sumber belajar bagi guru dan siswa dalam kegiatan pembelajaran. Keberhasilan suatu pembelajaran dipengaruhi oleh perangkat pembelajaran. Peneliti mengembangkan perangkat pembelajaran berupa Rencana Pelaksanaan Pembelajaran, Lembar Kerja Siswa dan Tes Akhir Pembelajaran. Penelitian ini bertujuan untuk mendeskripsikan suatu proses pengembangan dan menghasilkan perangkat pembelajaran matematika berbasis pemecahan masalah pada materi Pythagoras kelas VIII SMP. Penelitian yang akan dilakukan ini termasuk penelitian pengembangan dengan metode dari Plomp. Subjek dalam penelitian ini ialah siswa kelas VIII SMPN 4 Nganjuk. Instrumen penelitian terdiri dari perangkat pembelajaran, lembar validasi, rubrik penilaian lembar validasi, lembar pengamatan keterlaksanaan pembelajaran, rubrik penilaian pengamatan pembelajaran, lembar aktivitas siswa, dan angket respon siswa. Penelitian ini memperoleh hasil bahwa terpenuhinya kritera valid pada perangkat pembelajaran dengan total kevalidan RPP, TAP dan LKS 3.93, 3.83 dan 3.67. Hasil kepraktisan semua perangkat pembelajaran termasuk dalam kategori dapat digunakan dengan revisi kecil. Dalam keterlaksanaan pembelajaran diperoleh nilai total kepraktisan 3.69 kategori sangat baik. Aktivitas siswanya tergolong dalam kategori sangat aktif dengan perolehan nilai total $98.68 \%$. Pada penilaian keefektifan untuk semua perangkat pembelajaran ini, pada angket respon siswa tergolong dalam kategori positif dengan perolehan lebih dari $50 \%$. Hal tersebut juga tergolong dalam kriteria kuat dan sangat kuat. Selain itu untuk ketuntasan klasikal diperoleh $82.14 \%$.
\end{abstract}

Kata Kunci: Pengembangan Perangkat Pembelajaran, Pemecahan Masalah.

\section{Abstract}

Learning devices are a collection of learning resources for teachers and students in learning activities. The success of a learning process is influenced by learning tools. Researchers develop learning tools in the form of RPP, LKS and TAP. This study aims to describe a development process and produce mathematics-based learning tools for problem solving in the Pythagorean VIII grade of junior high school. This research is a development research using Plomp method. The subjects in this study were students of class VIII-6 SMPN 4 Nganjuk. The research instrument consisted of learning tools, validation sheets, validation sheets assessment rubrics, learning implementation observation sheets, learning observation assessment rubrics, student activity sheets, and student response questionnaires. This study found that the learning kit fulfilled validity criteria with a total RPP, TAP and LKS 3.93, 3.83 and 3.67. The practical results of all learning tools included in the category can be used with minor revisions. In the implementation of learning obtained a total of 3.69 with a very good category. Student activities are classified as very active with a total of $98.68 \%$. In the effectiveness assessment for all of these learning tools, the questionnaire responses of students belong to the positive category with the acquisition of more than $50 \%$. It also belongs to the criteria of strong and very strong. In addition to classical completeness obtained $82.14 \%$.

Keywords:Development of Learning tools, Problem Solving Learning.

\section{PENDAHULUAN}

Matematika ialah sebagian ilmu yang diajarkan di sekolah. Soedjadi (1999) mengemukakan bahwa matematika ialah salah satu ilmu dasar yang berperan penting dalam penguasaan ilmu pengetahuan dan teknologi. Sebagai ilmu dasar, matematika perlu diajarkan dengan maksimal sehingga siswa dapat memahaminya dengan baik. Salah satu materi dalam mata pelajaran matematika ialah Teorema Phytagoras. Berdasarkan Permendikbud tahun 2016 tentang kompetensi dasar, materi Teorema Phytagoras diajarkan di jenjang Sekolah Menengah Pertama (SMP) kelas VIII yang salah satu isinya 
ialah menerapkan Teorema Pythagoras dalam memecahkan masalah. Menurut Fitriyani (2014) teorema Pythagoras merupakan materi prasyarat dalam mempelajari materi-materi yang berkaitan dengan Geometri dalam kelas VIII dan kelas IX. Hidayanti (2016) menyebutkan bahwa materi teorema Phytagoras adalah salah satu pokok bahasan matematika yang mempunyai kesulitan tersendiri karena permasalahan dalam kehidupan sehari-hari yang menyangkut Teorema Phytagoras masih sulit untuk divisualisasikan. Oleh karena itu, siswa harus memahami dan mengerti teorema Pythagoras dengan benar yang nantinya bisa diterapkan dalam menyelesaikan masalah. Selain itu akan tercapainya pula tujuan pembelajaran. Dalam penelitian yang akan dilakukan ini kompetensi Dasar yang digunakan ialah 3.6 dan 4.6 yakni penjelasan dan pembuktian teorema Pythagoras dan tripel Pythagoras. Menyelesaiakan permasalahan dengan teorema Pythagoras dan tripel Pythagoras.

Menurut Hidayanti (2016) salah satu pemasalahan yang dihadapi oleh guru matematika ialah prestasi belajar matematika siswa lebih rendah dibanding mata pelajaran yang lain. Selain itu Hidyanti (2016) juga menyatakan bahwa sering ditemukan guru mendominasi dalam suatu proses pembelajaran, hal itu menyebabkan siswa pasif. Sehingga perlu dikembangkan suatu metode pembelajaran matematika yang dapat meminimalisir hal tersebut yaitu dengan pembelajaran berbasis pemecahan masalah. Polya (1973) menyampaikan bahwa pemecahan masalah termasuk kegiatan untuk menemukan penyelesaian dari masalah sehingga dapat tercapai suatu tujuan yang memerlukan waktu lama.

Siswono (2008, 35), "Pemecahan masalah adalah suatu proses atau upaya individu untuk merespon atau mengatasi halangan atau kendala ketika suatu jawaban atau metode jawaban belum nampak jelas."

Menurut Alipandie (1984:105) pembelajaran berbasis pemecahan masalah (Problem Solving) merupakan strategi pengajaran yang dilakukan dengan melatih siswa menyelesaikan masalah untuk dipecahkan sendiri atau secara berkelompok. Tujuan dari pembelajaran berbasis pemecahan masalah menurut NCTM ialah untuk (1) membentuk pengetahuan matematika baru, (2) menyelesaikan masalah dalam matematika dan dalam konteks lainnya, (3) menerapkan bermacam cara yang sesuai dalam pemecahan masalah, dan (4) memantau proses memecahkan masalah. Menurut Majid (2015:213) kegiatan dalam model pembelajaran berbasis Pemecahan Masalah dijelaskan sebagai berikut: (1) Mempersiapkan opini yang jelas untuk diselesaiakn. (2) Merumuskan apa yang ingin dicapai. (3) Menemukan data. (4) Menentukan penyelesaian sementara. Pada langkah tersebut, siswa berusaha menyelesaikan permasalahan dan meyakini bahwa penyelesaian tersebut cocok atau tidak dengan penyelesaian sementara. (5) Menampilkan penyelesaian dari masing-masing kelompok. (6) Membuat kesimpulan.

Dalam Kamus Besar Bahasa Indonesia (2002: 719) masalah adalah sesuatu yang harus dicari penyelesaiannya. Siswono (2008: 34) mengungkapkan bahwa masalah diartikan seuatu pertanyaan satu individu atau lebih namun tidak mempunyai peraturan, langkah tertentu untuk dapat dipergunakan untuk menentukan jawaban. Selain itu Suherman, dkk (2003: 92) menyatakan bahwa permasalahan memuat kondisi yang membuat individu segera menyelesaikannya, akan tetapi tidak langsung mengerti langkah apa yang harus dikerjakan untuk menyelesaikan kondisi tersebut. Hal tersebut dapat diartikan bahwa jika suatu permasalahan diberikan ke siswa, maka siswa tersebut tidak akan langsung mengetahui jawaban dengan benar melainkan diperlukan suatu proses dalam memecahkan suatu masalah.

Menurut Hudojo (2001: 63) menjelaskan bahwa pertanyaan yang termasuk dalam kategori masalah ialah yang memenuhi syarat sebagai berikut: (1) Pertanyaan harus dapat dimengerti dan tergolong tantangan. (2) Pertanyaan tersebut mengandung beberapa proses penyelesaian yang secara langsung tidak diketahui siswa. Sehingga diperluka waktu yang cukup dan sesuai dengan proses pemecahan masalah. Berdasarkan uraian itu, dapat disimpulkan permasalahan matematika merupakan soal matematika siswa yang mana siswa tersebut tidak memiliki cara tetap yang dipergunakan dengan segera untuk menentukan jawabannya.

Apabila siswa sudah baik dalam menyelesaikan soal lower order thingking (berpikir tingkat rendah), sebaiknya dilatih soal higher order thinking (berpikir tingkat tinggi) agar dapat meningkatkan kemampuan matematika siswa.. Dari sinilah peran guru dalam pembelajaran sangat dibutuhkan. Tidak hanya sekedar mengarahkan siswa untuk menyelesaikan soal-soal yang sederhana atau sama seperti yang dicontohkan, melainkan melatih siswa untuk menyelesaikan suatu permasalahan matematika yang menantang atau dalam kategori Higher Order Thinking (HOT).

Higher order thinking (HOT) atau berpikir tingkat tinggi yang semestinya dipunyai oleh setiap siswa meskipun dalam kenyataannya jarang atau bahkan tidak pernah diberikan. Resnick (1987: 3), "Higher order thinking often yields multiple solutions, each with costs and benefits, rather than unique solutions. Higher order thinking involves nuanced judgment and interpretation. Higher order thinking involves the application of multiple criteria, which sometimes conflict with one another. Higher order thinking often involves uncertainly. Not everything that bears on the task at hand is known. Higher order thinking involves self-regulation of the thinking process. We do not recognize higher order thinking in an individual 
when someone else "calls the plays" at every step. Higher order thinking involves imposing meaning, finding structure in apparent disorder."

Berdasarkan uraian diatas, dapat disimpulkan bahwa Higher Order Thinking (HOT) yang terdapat di Lembar Kerja Siswa dan Tes Akhir Pembelajaran menekankan pada permasalahan matematika yang melibatkan ketidakpastian dan membutuhkan banyak usaha untuk menyelesaikannya. Jawaban siswa tidak dapat dipastikan sama dengan persepsi peneliti. Selain itu, masalah matematika tipe HOT tidak termasuk masalah sederhana yang mudah diselesaikan tanpa menganalisis permasalahan.

Hidayanti (2016) menyatakan bahwa RPP sangat berpengaruh dalam proses pembelajaran. Sehingga guru seharusnya menyusun perangkat pembelajaran agar tercapainya tujuan pembelajaran. Akan tetapi, banyak guru yang jarang membuat perangkat pembelajaran. Perangkat pembelajaran ialah beberapa sumber belajar yang membuat guru dan siswa melakukan kegiatan pembelajaran (Khabibah, 2006). Perangkat pembelajaran yang dikembangkan dalam penelitian ini meliputi Rencana Pelaksanaan Pembelajaran (RPP), Lember Kerja Siswa (LKS), dan Tes Akhir Pembelajaran (TAP). Dalam Permendikbud Nomor 22 Tahun 2016 menyatakan bahwa Rencana Pelaksanaan Pembelajaran (RPP) ialah rencana pembelajaran secara detail dikembangkan dari suatu materi utama dan sesuai dengan silabus. RPP dibuat untuk menuntun kegiatan belajar siswa agar terccapainya Kompetensi Dasar (KD). Sedangkan Lembar Kerja Siswa (LKS) merupakan lembar pekerjaan yang harus dikerjakan oleh siswa, yang berisi petunjuk dan langkah-langkah untuk menyelesaikan suatu pekerjaan (Depdiknas, 2008). LKS dibuat untuk mempermudahkan tenaga pendidik dalam melakukan pembelajaran dan untuk belajar mandiri dalam suatu tugas tertulis untuk siswa. Selain itu Tes Akhir Pembelajaran (TAP) digunakan untuk mengevaluasi hasil pembelajaran siswa dalam satu kurun waktu tertentu. Dalam lembar penilaian terdapat butir-butir soal tes sebagai alat ukur ketercapaian tujuan pembelajaran. Fitriani (2014) menyatakan bahwa seorang tenaga pendidik harusnya menyiapkan materi yang mau diajarkan, alat praktikum yang akan digunakan, pertanyaan untuk siswa, mengetahui kondisi siswa, serta mempelajari pengetahuan awal siswa sebelum kegiatan pembelajaran dilakukan. Sehingga diperlukannya dalam melakukan perencanaan pembelajaran, pelaksanaan proses pembelajaran dan evaluasi proses pembelajaran.

Dalam proses pembelajaran, sangat diperlukan perangkat pembelajaran. Disisi lain juga sangat diperlukan pula perangkat pembelajaran yang tepat agar tercapainya tujuan belajar yang telah ditetapkan. Khabibah (2006) mengungkapkan bahwa perangkat pembelajaran yang mampu mendorong pembelajaran hingga tercapainya tujuan yang diharapkan merupakan ciri perangkat pembelajaran yang baik. Dalam penelitian ini, suatu perangkat pembelajaran dapat dinyatakan tepat jika terpenuhi kriteria kualitas perangkat pembelajaran yang diadaptasi dari kriteria Nieveen (1999) yaitu kevalidan (validity), kepraktisan (practicality), dan keefektivan (effectiveness).

Menurut Nieveen (1999), "The components of the intervention should be based on state of the art knowledge (content validity) and all components should be consistently linked to each other (construct validity). If the intervention meets these requirements it is considered to be valid." Penelitian ini memuat indikator untuk kevalidan RPP yang digunakan ialah aspek format, tujuan, bahasa, waktu, dan isi yang dimodifikasi sesuai dengan kebutuhan peneliti. Untuk indikator kevalidan yang dimuat dalam LKS yang digunakan ialahaspek format, bahasa, dan isi. Sedangkan indikator yang dimuat dalam kevalidan Tes Akhir Pembelajaran yang digunakan mencakup aspek materi, konstruksi, dan bahasa.

Aspek kepraktisan menurut Nieveen (1999), “ $A$ second characteristic of high-quality materials is that teachers (and other experts) consider the materials to be usable and that it is easy for teachers and students to use the materials in a way that is largely compatible with the developers' intentions. This means that consistency should exist between the intended and perceived curriculum and the intended and operational curriculum. If both consistencies are in place, we call these materials pratical." Dalam penelitian ini indikator kepraktisan perangkat pembelajaran adalah diukur berdasarkan penelitian validator mengenai dapat digunakan atau tidak dan juga berdasarkan pelaksanaan pembelajaran dan aktivitas siswa.

Aspek keefektifan menurut Nieveen (1999), “A third characteristic of high quality materials is that students appreciate the learning program and that desired learning takes place. With such effective materials, consistency exist between the intended and experiential curriculum and the intended and attained curriculum." Berdasarkan penjelasan diatas, indikator keefektifan ialah respon siswa menunjukkan komentar siswa mengenai kegiatan pembelajaran dan perangkat pembelajaran yang dikembangkan. Selain itu diukur dari hasil belajar yang menunjukkan tingkat pencapaian kompetensi siswa setelah mengikuti pembelajaran.

Berdasarkan uraian di atas, peneliti bermaksud mengembangkan perangkat pembelajaran berupa Rencana Pelaksanaan Pembelajaran (RPP), Lembar Kegiatan Siswa (LKS) dan Tes Akhir Pembelajaran (TAP) berbasis pemecahan masalah pada materi Pythagoras Kelas VIII SMP yang valid, praktis, dan efektif. Oleh karena itu 


\section{PENGEMBANGAN PERANGKAT PEMBELAJARAN...}

peneliti merumuskan beberapa pertanyaan penelitian diantaranya

1. Bagaimanakah prosedur pengembangan perangkat pembelajaran matematika berbasis pemecahan masalah pada materi Pythagoras kelas VII SMP?

2. Bagaimanakah hasil peneliti mengembangkan perangkat pembelajaran matematika berbasis pemecahan masalah pada materi Pythagoras kelas VII SMP yang baik?

Sehingga dari pertanyaan penelitian tersebut, peneliti memiliki tujuan penelitian yang akan dicapai, yaitu

1. Mendeskripsikan proses pengembangan perangkat pembelajaran matematika berbasis pemecahan masalah kategori menemukan pada materi Pythagoras kelas VII SMP.

2. Menghasilkan pengembangan perangkat pembelajaran matematika berbasis pemecahan masalah kategori menemukan pada materi METODE

Pythagoras kelas VII SMP yang baik.

Penelitian tersebut merupakan penelitian pengembangan, sebab peneliti akan mengembangkan perangkat pembelajaran matematika berbasis pemecahan masalah pada materi Pythagoras kelas VII SMP yang meliputi Rencana Pelaksanaan Pembelajaran (RPP), Lembar Kerja Siswa (LKS), dan Tes Akhir Pembelajaran (TAP) yang tergolong dalam kriteria kevalidan, kepraktisan dan keefektifan. Peneliti menggunakan model pengembangan Plomp (2010) yang meluputi tahapan penelitian awal (preliminary phase), tatapan pembuatan prototipe (prototyping phase), dan tahapan evaluasi (assessment phase). Dalam penelitian ini, subjek uji cobanya ialah siswa kelas VIII-6 Sekolah Menengah Pertama di kabupaten Nganjuk. Pelaksanaan penelitian ini dilaksanakan pada awal semester genap pada materi Pythagoras.

Prosedur peneitian yang akan dilakukan meliputi tahapan persiapan, tahapan pelaksanaan, tahapan analisis data, dan tahapan penulisan laporan. Penelitian ini menggunakan desain pengembangan seperti yang disajikan dalam Gambar 1 berikut.

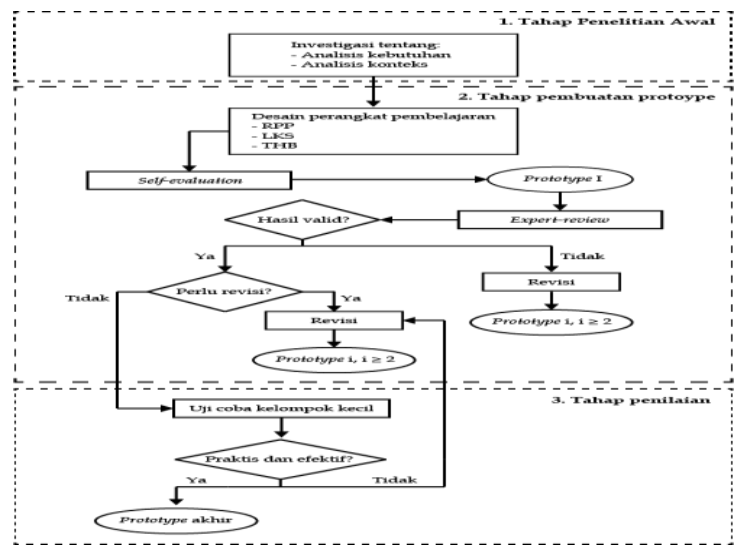

Gambar 1. Alur Model Pengembangan Plomp (2010)
Keterangan:

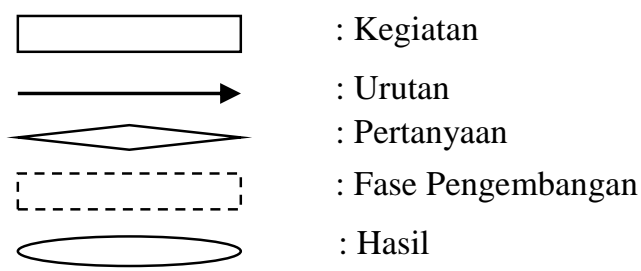

Penjelasan desain Plomp diatas ialah kegiatan yang dilakukan peneliti, untuk tahapan penelitian awal ialah menganalisis kebutuhan dan konteks. Dilanjutkan dengan aktivitas yang dilakukan dalam tahap pembuatan prototipe diantaranya perancangan dan pengembangan. Pada pengembangan dilakukan kegiatan self-evaluation terhadap perangkat pembelajaran oleh peneliti sendiri dengan bantuan dosen pembimbing dihasilkan prototipe 1 , expert riview meminta validator untuk menilai kevalidan prototipe. Dan yang terakhir pengujian produk melalui grup kecil, dilakukan pengujian lingkup kecil mengenai perangkat pembelajaran yang telah dinyatakan valid tanpa revisi atau sedikit revisi. Tahap ini dilaksanakan untuk mendapatkan data kepraktisan dan keefektifan perangkat pembelajaran. Tahap selanjutnya ialah tahapan evaluasi untuk penentuan kelayakan. Evaluasi dilakukan dengan analisis praktis dan efektiv perangkat pembelajaran hasil pengujian lingkup kecil.

Penelitian ini menggunakan data kevalidan, data kepraktisan, data keterlaksanaan pembelajaran, data aktivitas siswa, data angket respon siswa dan data hasil belajar siswa. Sedangkan intrumen data meliputi instrumen validasi perangkat pembelajaran, instrumen pengamatan kegiatan siswa, instrumen penilaian respons siswa, dan instrumen penilaian hasil pembelajaran siswa.

Analisis data yang akan dilakukan meliputi analisis kevalidan yang diadaptasi dari Khabibah (2006) dengan mencocokkan total kevalidan dengan kategori yang telah ditetapkan. Selain itu, dalam menganalisis kepraktisan dilakukan dengan pernyataan validator mengenai perangkat pembelajaran dapat dipergunakan dengan revisi yang sedikit atau tidak ada revisi, keterlaksanaan pembelajaran dengan mencocokkan total umum dengan kategori yang diadaptasi dari Khabibah (2006) telah ditetapkan. Dilanjutkan dengan aktivitas siswa dengan mencocokkan hasil total terhadap kriteria yang diadabtasi dari Khabibah (2006).

Analisis yang terakhir ialah analisis keefektifan yang dilihat dari angket respon siswa dan hasil belajar siswa.. Untuk menentukan kriteria respon siswa tiap butir pernyataan dengan kategori yang diadaptasi dari Riduwan (dalam Septyanto, 2016) telah ditetapkan. Ketuntasan hasil belajar individu ini dapat dicapai apabila skor yang diproleh siswa mencapai 71 (skor maksimal 100). Dan 
untuk menghitung ketuntasan hasil belajar klasikal ialah dengan rumus

$\%$ Ketuntasan Klasika $=\frac{\text { Banyak siswa tuntas }}{\text { seluruh siswa }} \times 100 \%$

Keefektifan perangkat pembelajaran harus memenuhi ketuntasan hasil belajar klasikal yaitu $75 \%$.

\section{HASIL DAN PEMBAHASAN}

Perangkat pembelajaran dikembangkan dengan alur pengembangan Plomp. Hasil dari wawancara peneliti dengan guru matematika kelas VIII-6 diantaranya: (1) Kurikulum yang digunakan di SMPN 4 Nganjuk ialah Kurikulum 2013. (2) Kegiatan pembelajaran yang dilakukan masih sering terfokus pada guru. Sehingga siswa kurang aktif dalam pembelajaran. (3) Guru jarang memberi celah siswa untuk bertanya bagaimana menemukan kembali rumus yang ada. (4) LKS yang digunakan masih sesuai dengan LKS umum penerbit yang belum memuat cara untuk menemukan kembali rumus yang disediakan. (5) Dari beberapa RPP yang digunakan guru, belum terdapat RPP dengan model pembelejaran berbasis pemecahan masalah, khususnya pada materi Pythagoras. (6) Para siswa di Kelas VIII-6 sudah memiliki pengetahuan awal mengenai akar kuadrat, dan jenis-jenis segitiga. (7) Para siswa di Kelas VIII-6 mempunyai kemampuan matematika yang sedang. (8) Kompetensi Dasar (KD) pada materi Pythagoras ini ialah 3.6 yaitu penjelasan dan pembuktian teorema Pythagoras dan tripel Pythagoras. KD 4.6 yaitu penyelesaian masalah dengan teorema Pythagoras dan tripel Pythagoras.

Berdasarkan KD 3.6 dan 4.6, peneliti menyusun beberapa indikator pencapaian, diantaranya: Menemukan kembali Teorema Pythagoras. Menentukan berapa panjang salah satu sisi segitiga sikusiku jika panjang dua sisinya diketahui. (3) Memenukan jenis segitiga dengan melihat panjang sisi-sisi yang diketahui. (4) Memecahkan permasalahan yang berkenaan dengan teorema Pythagoras dan tripel Pythagoras.

Berdasarkan indikator dan Kompeten Dasar tersebut, peneliti menyusun beberapa tujuan pembelajaran, diantaranya: (1) Siswa dapat menemukan kembali Teorema Pythagoras. (2) Siswa dapat Menentukan berapa panjang salah satu sisi segitiga siku-siku jika panjang dua sisinya diketahui. (3) Siswa dapat Memenukan jenis segitiga dengan melihat panjang sisi-sisi yang diketahui. (4) Siswa dapat menggunakan teorema Pythagoras dan tripel Pythagoras untuk memecahkan masalah matematika dengan benar.

Dilanjutkan dengan tahap penelitian awal yaitu kegiatan perancangan dan pengembangan. RPP, LKS dan TAP yang dikembangkan dipergunakan untuk dua pertemuan. Pada pertemuan pertama, sub materi yang digunakan ialah menjelaskan dan membuktikan teorema
Pythagoras dan tripel Pythgoras. Sedangkan pada pertemua kedua, sub materi yang digunakan ialah penyelesaian terhadap masalah yang berkenaan dengan teorema Pythagoras dan tripel Pythagoras.

Pada kegiatan self-evaluation dalam tahap pengembanagan diperoleh hasil dari evaluasi oleh peneliti sendiri ialah tidak ada yang perlu direvisi. Kemudian peniliti mengkonsultasikan kepada dosem pembimbing dan diperoleh beberapa hal yang perlu revisi. Berikut merupakan penjabaran hal-hal yang perlu direvisi, tersedia dalam Tabel 1.

Tabel 1. Revisi RPP oleh Dosen Pembimbing

\begin{tabular}{|c|c|}
\hline Sebelum Revisi & Setelah Revisi \\
\hline $\begin{array}{l}\text { 1. Tidak disebutkan fase } \\
\text { dalam langkah- } \\
\text { langkah pembelajaran } \\
\text { yang terdapat pada } \\
\text { RPP pertemuan } \\
\text { pertama dan kedua. }\end{array}$ & $\begin{array}{l}\text { 1. Dicantumkan fase- } \\
\text { fase dalam langkah- } \\
\text { langkah pembelajaran } \\
\text { yang terdapat pada } \\
\text { RPP untuk pertemuan } \\
\text { pertama dan kedua }\end{array}$ \\
\hline $\begin{array}{ll}\text { 2. } & \text { Pemaparan tujuan } \\
\text { dalam RPP tidak ditulis } \\
\text { dalam poin-poin. }\end{array}$ & $\begin{array}{lll}\text { 2. } & \text { Pemaparan tujuan } \\
\text { dalam RPP ditulis } \\
\text { dalam poin-poin. }\end{array}$ \\
\hline
\end{tabular}

Setelah dilakukan revisi akan menghasilkan prototipe, yang selanjutnya akan dilakukan evaluasi oleh expert riview atau validator perangkat pembelajaran yang berupa prototipe 1. Total kevalidan RPP untuk dua pertemuan $\left(\mathrm{V}_{\mathrm{RPP}}\right.$ ) sama yaitu 3.93 dan termasuk dalam kategori sangat valid. Dalam penelitian ini ketersesuaian indikator dengan Kompetensi Dasar ditunjukkan oleh penilaian validator mengenai aspek ketepatan penjabaran indikator sesuai dengan Kompetensi Dasar (KD) yaitu sebesar 3.50 untuk RPP dua pertemuan sekaligus. Selain itu juga memuat sintaks pembelajaran yang sesuai pada langkah-langkah pembelajaran berbasis pemecahan masalah. Hal tersebut telah dibuktikan oleh penilaian validator yang mencapai 4.00. Namun ada beberapa kritikan sekaligus saran validator mengenai kesalahan yang harus direvisi dari RPP untuk pertemuan pertama dan kedua. Sehingga dilakukannya revisi oleh peneliti. Berikut merupakan penjabaran hasil sebelum revisi dan setelah revisi dalam Tabel 2.

Tabel 2. Revisi RPP oleh Validator

\begin{tabular}{|ll|lr|}
\hline \multicolumn{2}{|c|}{ Sebelum Revisi } & \multicolumn{2}{|c|}{ Setelah Revisi } \\
\hline 1. & $\begin{array}{l}\text { Materi belum lengkap } \\
\text { karena belum adanya } \\
\text { materi mengenai jenis- } \\
\text { jenis segitiga }\end{array}$ & $\begin{array}{l}\text { Adanya materi } \\
\text { mengenai jenis-jenis } \\
\text { segitiga }\end{array}$ \\
\hline $\begin{array}{l}\text { 2. } \\
\text { Kesalahan beberapa } \\
\text { penulisan kata. }\end{array}$ & $\begin{array}{l}\text { Perbaikan penulisan } \\
\text { kata yang salah }\end{array}$ \\
\hline
\end{tabular}

Adapun kegiatan dalam RPP untuk pertemuan pertama dan kedua ini mengacu pada pemecahan masalah, yang bisa 
membantu siswa mampu mempergunakan seluruh pengetahuan, ketrampilan, dan kemampuan yang mereka miliki untuk menyelesaikan masalah yang bersifat tidak rutin atau tidak sering mereka jumpai. Selain itu siswa juga dapat berlatih dalam menggunakan konsep-konsep matematika yang telah didapatkan sebelumnya untuk menyelesaikan masalah tersebut. Hal tersebut sesuai dengan tujuan pembelajaran berbasis pemecahan masalah menurut NCTM.

Total kevalidan LKS untuk pertemuan pertama dan kedua ( $\mathrm{V}_{\text {LKS }}$ ) ialah 3.83 dan dalam kategori sangat valid. Ada beberapa kritikan sekaligus masukan dari validator mengenai kesalahan pada LKS untuk dua pertemuan. Sehingga dilakukannya revisi oleh peneliti. Berikut merupakan penjabaran hasil sebelum revisi dan setelah revisi dalam Tabel 3 .

Tabel 3. Revisi LKS oleh Validator

\begin{tabular}{|c|c|}
\hline Sebelum Revisi & Setelah Revisi \\
\hline $\begin{array}{lr}\text { 1. } & \text { Pada gambar } \\
\text { pembuktian teorema } & \text { tidak } \\
\text { Pyhtagoras, gambar } & \text { disajikan an dan } \\
\text { dengan panjang a dan } \\
\text { b berbeda, sehingga } \\
\text { kesimpulannya } \\
\text { berlaku secara umum. }\end{array}$ & $\begin{array}{l}\text { Gambar pada } \\
\text { pembuktian } \\
\text { Pythagoras disajikan } \\
\text { dengan panjang a dan } \\
\text { b berbeda }\end{array}$ \\
\hline $\begin{array}{lll}\text { 2. } & \text { Ada rumus yang } \\
\text { kurang tepat }\end{array}$ & $\begin{array}{l}\text { 2. Perbaikan rumus secara } \\
\text { tepat }\end{array}$ \\
\hline $\begin{array}{ll}\text { 3. } & \text { Berikan siswa } \\
\text { mengidentifikasi } \\
\text { sendiri jenis-jenis } \\
\text { segitiga. }\end{array}$ & $\begin{array}{l}\text { 3. Siswa dapat } \\
\text { mengidentifikasi jenis- } \\
\text { jenis segitiga } \\
\text { berdasarkan } \\
\text { kesimpulan. }\end{array}$ \\
\hline
\end{tabular}

Dalam mengembangkan perangkat pembelajaran Lembar Kerja Siswa (LKS), peneliti menggunakan komponen-kompenen diantaranya ialah judul, petunjuk, langkah-langkah dalam soal, serta materi pendukung. Dalam LKS ini salah satu materi pendukung disajikan dalam kesimpulan. Selain itu petunjuk yang ada dalam LKS ini disediakan disetiap indikator. Kemudian dilanjutkan dengan permasalahan-permasalahan yang disajikan dan terbagi sesuai dengan indikator pencapaian. Masalah yang digunakan dalam LKS ini merupakan soal HOT tipe menemukan. Hal tersebut dapat dibuktikan dengan hasil dari penilaian validator pada kriteria masalah yang diangkat. Dengan perolehan sebesar 3.00 untuk LKS dua pertemuan. Dan pada pengisian angket respon siswa di pernyataan ke 2 juga mendapat presentase $81.14 \%$ dan termasuk dalam kategori sangat kuat. Disisi lain, LKS yang disediakan peneliti juga menarik karena desain gambar yang tidak terlalu berlebihan. Hal itu telah ditunjukkan pada angket respon siswa yang terdapat pada pernyataan 7 dan 9. Diperoleh persentase sebesar $65.57 \%$ dan $75.40 \%$ yang termasuk dalam kategori kuat. Pada jawaban siswa yang ada di LKS, terdapat satu kelompok yang kurang tepat dalam penulisan simbol sama dengan “="seperti pada Gambar 2

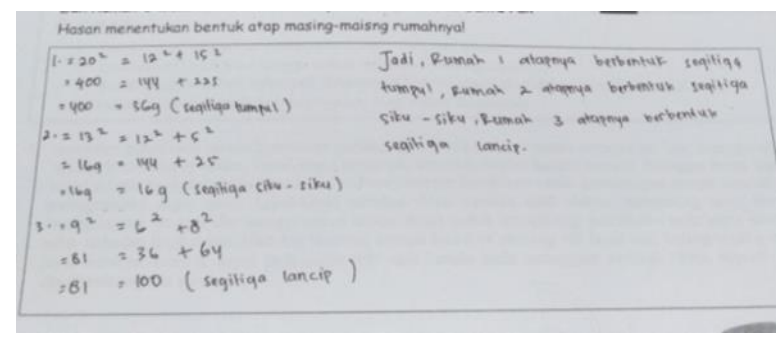

Gambar 2. Hasil Pekerjaan Siswa pada LKS 1

Hal itu terdapat pada LKS 1 pada soal dengan indikator menemukan bentuk segitiga dilihat dari panjang sisi-sisi yang diketahui. Namun kesalahan ini tidak mempengaruhi pada jawaban siswa. Karena jawaban siswa tersebut benar.

Total kevalidan TAP untuk pertemuan pertama dan kedua $\left(\mathrm{V}_{\mathrm{TAP}}\right.$ ) ialah 3.67 termasuk dalam kategori sangat valid. Ada kritikan dan masukan dari validator mengenai kesalahan pada TAP untuk dua pertemuan. Sehingga dilakukannya revisi oleh peneliti. Berikut merupakan penjabaran hasil sebelum revisi dan setelah revisi dalam Tabel 4.

Tabel 2. Revisi TAP oleh Validator

\begin{tabular}{|ll|lr|}
\hline \multicolumn{2}{|l|}{ Sebelum Revisi } & \multicolumn{2}{|c|}{ Setelah Revisi } \\
\hline $\begin{array}{l}\text { 1. } \\
\text { Soal nomor } 3 \\
\text { konteksnya kurang } \\
\text { cocok. }\end{array}$ & $\begin{array}{l}\text { Perbaikan konteks pada } \\
\text { soal nomor 3 }\end{array}$ \\
\hline $\begin{array}{l}\text { Operasi matematika } \\
\text { yang digunakan juga } \\
\text { tidak tepat }\end{array}$ & $\begin{array}{l}\text { Perbaikan operasi } \\
\text { matematika secara } \\
\text { tepat. }\end{array}$ \\
\hline
\end{tabular}

Disisi lain, peneliti menyusun permasalahan sesuai dengan indikator pencapaian. Hal tersebut dapat dibuktikan pada nilai dari validator terhadap aspek ketepatan soal dengan indikator pencapaian, yang mendapat rataan tiap aspek sebesar 3.50 untuk TAP pertemuan pertama dan kedua. Permasalahan yang disediakan dalam TAP untuk pertemuan pertama dan kedua berupa soal esai. Peneliti menyusun permasalahan sesuai dengan indikator pencapaian. Hal tersebut dapat dibuktikan pada nilai dari validator mengenai aspek ketepatan soal dengan indikator pencapaian, yang mendapat rataan tiap aspek sebesar 3.50 untuk TAP pertemuan pertama dan kedua.

Namun pada TAP soal nomor 1 terdapat jawaban siswa tanpa menyertakan kata pemisalan. Sehingga menimbulkan pemahaman yang berbeda. Pada soal disebutkan bahwa perbandiangan sisi keduanya 4:5 dan pada jawaban siswa langsung disebutkan bahwa sisi nya ialah 4x dan 5x tanpa adanya kata "misal".

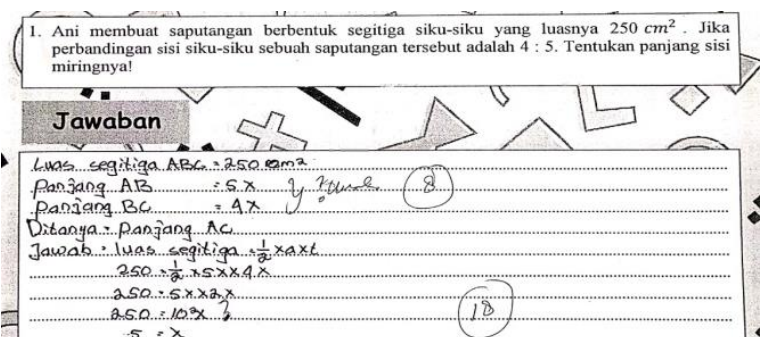




\section{Gambar 3. Hasil Pekerjaan Siswa pada TAP}

Berdasarkan penilaian dari validator mengenai kepraktisan suatu perangkat pembelajaran, diperoleh kepraktisan RPP, LKS dan TAP untuk pertemuan pertama dan kedua dapat dipergunakan dengan revisi yang sedikit. Disisi lain, rataan semua aspek dalam keterlaksanaan pembelajaran ialah 3.69 tergolong dalam kategori sangat baik. Dan total aktivits siswa ialah $98.68 \%$ termasuk dalam kategori sangat aktif. Rasa ikut serta siswa dalam kegiatan pembelajaran ini cukup luar biasa. Karena salah satu jenis aktivitas siswa yaitu berdiskusi dengan teman dalam mengkonstruk konsep secara mandiri sehingga dapat menyelesaikan suatu permasalahan yang memperoleh total sebesar $45.13 \%$ dari kedua pertemuan. Disamping itu, juga dapat dibuktikan melalui angket respon siswa untuk aspek ke $1,3,5,7.9,11,13$ dan 15 yang masing-masing mendapat persetase $79.50 \%, 72.95 \%, 80.32 \%, 65.57 \%$, $75.40 \%, 81.96 \%$, $68.85 \%$, dan $71.31 \%$. Sehingga dapat disimpulkan bahwa 2 pernyataan dalam kategori sangat kuat dan 6 pernyataan dalam kategori kuat.

Dalam penelitian ini dilaksanakan kegiatan pemberian Tes Akhir Pembelajaran (TAP) pada akhir pembelajaran, baik pertemuan pertama dan kedua. Hasil dari TAP siswa ialah ada 23 siswa yang dinyatakan lolos dan 5 siswa yang dinyatakan tidak lolos. Ketuntasan hasil belajar klasikal untuk dua pertemuan diperoleh sebanyak $82.14 \%$ dan memenuhi kriteria efektif. Selain itu, pada angket respon siswa terdapat 3 pernyataan yang mendapat respon sangat kuat, 12 pernyataan mendapat respon kuat, dan 1 pernyataan yang mendapat respon cukup. Berdasarkan hasil respon siswa menunjukan bahwa 50\% tergolong dalam kriteria kuat dan kategori positif untuk respon siswa.

\section{PENUTUP}

\section{Simpulan}

Sesuai dengan hasil dan tujuan penelitian, peneliti mendapatkan kesimpulan mengenai prosdur dan hasil dalam mengembangkan perangkat pembelajaran yang berupa RPP, LKS dan TAP. Prosedur pengembangan mengikuti alur pengembangan Plomp. Kegiatan yang dilakukan ialah tahapan penelitian awal, tahapan pembuatan prototipes, dan tahapan evaluasi. Pada tahapan penelitian awal, peneliti menganalisis konteks dan kebutuhan. Pada analasis kebutuhan diperoleh informasi mengenai kurikulum, metode pembelajaran, LKS dan RPP yang digunakan. Selain itu pada analisis konteks diperoleh informasi mengenai pengetahuan siswa tentang materi prasyarat dan kemampuan matematika siswa yang dilihat dari nilai Ujian Akhir Sekolah (UAS). Disamping itu dalam analisis konteks juga terdapat informasi mengenai Kompetensi Dasar (KD) yang digunakan, sehingga peneliti dapat menyusun tujuan pembelajaran dan indikator yang sesuai dengan KD.

Pada tahap pembuatan prototipe, peneliti membuat perangkat pembelajaran yang meliputi Rencana Pelaksanaan Pembelajaran (RPP), Lembar Kerja Siswa (LKS), dan Tes Akhir Pembelajaran (TAP). Kemudian dilanjutkan proses pengembangan. Pada proses pengembangan peneliti melakukan kegiatan selfevaluation, evaluasi dari peneliti dan juga devaluasi dari dosem pembimbing. Setelah dilakukannya self-evaluation, peneliti menyerahkan prangkat pembelajaran kepada validator untuk divalidasi. Validator untuk penelitian ini ada 2, yaitu dosen dari pendidikan matematika Universitas Negeri Surabaya dan guru mata pelajaran matematika di SMPN 4 Nganjuk. Kemudian langkah terakhir ialah dilakukan uji coba di kelas VIII-6 SMPN 4 Nganjuk tahun ajaran 2019-2020.

Pada tahapan evaluasi, peneliti menganalisis kepraktisan dan keefektifan. Kegiatan tersebut dilakukan setelah pengujian terbatas perangkat pembelajaran. Untuk menganalisis kepraktisan dilihat berdasarkan hasil validasi dari 2 validator, kemudian hasil pengamatan keterlaksanaan pembelajaran yang dilakukan oleh pengamat, dan pengamatan aktivitas siswa yang dilakukan oleh pengamat yaitu teman peneliti sendiri. Sedangkan untuk analisis keefektifan dilihat berdasarkan hasil angket respon siswa yang telah diisi dan juga nilai dari Tes Akhir Pembelajaran (TAP) untuk dua pertemuan.

Hasil pengembangan perangkat pembelajaran berbasis pemecahan masalah dilihat melalui kevalidan, kepraktisan dan keefektifan. Kevalidan untuk RPP untuk dua pertemuan tergolong dalam kategori sangat valid dengan perolehan total total 3.93. Untuk kevalidan LKS dua pertemuan juga tergolong dalam kriteria sangat valid dengan perolehan total total 3.83. Sedangkan untuk kevalidan TAP dua pertemuan tergolong dalam kriteria sangat valid dengan perolehan total total 3.67. Penilaian dari validator untuk kepraktisan termasuk dalam kategori dapat dipergunakan dengans revisi yang sedikit. Selain itu, dalam keterlaksanaan pembelajaran diperoleh total total 3.69 dengan kriteria sangat baik. Kemudian untuk aktivitas siswa termasuk dalam kategori sangat aktif dengan perolehan total total 98. 68\%. Pada penilaian keefektifan untuk perangkat pembelajaran yang dikembangkan peneliti ini, dilihat dari angket respon siswa yang tergolong dalam 
kategori positif dengan perolehan 50\% lebih yang tergolong dalam kriteria kuat dan sangat kuat. Selain itu untuk hasil dari TAP pertemuan pertama dan kedua juga memperoleh ketuntasan klasikal sebesar $82.14 \%$.

\section{Saran}

Setelah peneliti melakukan penelitian, ada beberapa saran yang diajukan oleh peniliti sendiri, diantaranya:

1. Siswa dapat menhkonstruk konsep saat mengikuti pembelajaran berbasis pemecahan masalah dan menjadikannya sebagai motivasi belajar matematika

2. Dalam mengembangkan perangkat pembelajaran berbasis pemecahan masalah lebih baik ditujukan untuk materi lainnya sehingga mampu meningkatkan daya tarik siswa dan keaktifan siswa dalam belajar matematika.

\section{DAFTAR PUSTAKA}

Alipandie, Imansyah (1984). Didaktik Metodik Pendidikan Umum. Surabaya: Usaha Nasional.

Depdiknas. 2002. Kamus Besar Bahasa Indonesia. Jakarta : Balai Pustaka.

Depdiknas. 2008. Pengembangan Bahan Ajar. Direktorat Pembinaan Sekolah Menengah Atas Direktorat Jenderal Manajemen Pendidikan Dasar dan Menengah Departemen Pendidikan Nasional.

Suparno. 2000. Langkah-langkah Penulisan Artikel Ilmiah dalamSaukah, Ali dan Waseso, M.G. 2000. Menulis Artikel untuk Jurnal Ilmiah. Malang: UM Press.

Fitriani. 2014. Pengembangan Perangkat Pembelajaran Melalui Model Pembelajaran Kooperatif Tipe Jigsaw Untuk Meningkatkan Kemampuan Komunikasi Matematik Siswa Di Smp Kelas VIII, (online), (http:/digilib.unimed.ac.id/public/UNIMED-Master32833-8126171009, diakses 1 Oktober 2019)

Hidayanti, Dwi. 2016. Pengembangan Perangkat Pembelajaran Berbasis Pemecahan Masalah Untuk Meningkatkan Kemampuan Berpikir Kritis Siswa SMP Kelas IX. Malang: Pendidikan PascasarjanaUniversitas Negeri Malang.

Hudojo, Herman. 2001. Pengembangan Kurikulum dan Pembelajaran Matematika. Malang: Jurusan Pendidikan FMIPA Universitas Negeri Malang.
Khabibah, Siti. 2006. Pengambangan Model Pembelajaran Matematika dengan Soal Terbuka untuk Meningkatkan Kreatifitas Siswa Sekolah Dasar. Disertasi tidak diterbitkan. Surabaya. Universitas Negeri Surabaya.

Majid, Abdul. 2015. Strategi Pembelajaran. Bandung: PT Remaja Rosadakarya

NCTM. 1990. Curriculum and Evaluation Standards for School Mathematics. Reston : VA.

NCTM. 2000. Principles and standards for School Mathematics. Reston : VA..

Nieveen, N. 1999. Prototyping to Reach Product Quality. Dalam Plomp, T; Nieveen, N; Gustafson, K; Branch, R.M; dan van den Akker, J (eds). Design Approaches and Tools in Education and Training. London: Kluwer Academic Publisher.

Peraturan Menteri Pendidikan dan kebudayaan RI No. 22 tahun 2016 tentang Standar Proses Untuk Pendidikan Dasar dan Menengah.

Plomp, Tjeerd. 2010. Educational Design Research : An Introduction. Dalam Tjeerd Plomp \& Nienke Nieveen. 2010. An Introduction to Educational Design Research. Netherland: Netzodruk, Enschede.

Polya, G. 1973. How to solve it. New Jersey: Priceton University Press.

Resnick, L.B. 1987. Education an Learning to Think. Washington DC : National Academy Press.

Septyanto, D. 2016. Pengembangan Perangkat Pembelajaran Matematika dengan Pendekatan Kontekstual Pada Materi Trigonometri Untuk Siswa SMK Jurusan Teknik Pemesinan. Surabaya.

Siswono, Tatag Yuli eko. 2008. Model Pembelajaran Matematika Berbasis Pengajuan dan Pemecahan Masalah Untuk Meningkatkan Kemampuan Berpikir Kreatif. Surabaya : Unesa University Press.

Soedjadi, dkk. 1999. Kiat Pendidikan Matematika dan Indonesia. Direktorat Jendral Pendidikan Tiinggi Departemen Pendidikan Nasional.

Suherman, dkk. 2003. Strategi Pembelajaran Matematika Kontemporer. Bandung: JICA-UPI. 